\title{
ANALYSIS OF RELIABILITY OF AUTOMATIC CORE PROTECTION FUNCTION OF THE REACTOR V-412 IN RESPONSE TO LOCAL PARAMETERS: MAXIMUM LINEAR POWER, DEPARTURE FROM NUCLEATE BOILING RATIO
}

\author{
S.S. Lys ${ }^{1}$, M.M. Semerak ${ }^{1}$, A.I. Kanyuka ${ }^{2}$ \\ ${ }^{1}$ Lviv Polytechnic National University, Lviv, Ukraine; \\ ${ }^{2}$ Belarusian NPP, Belarus \\ E-mail:lysss@ukr.net
}

\begin{abstract}
The research subject is finding an engineering solution for $\mathrm{V}-412$ core automatic protection during operation in both steady-state and transient conditions within ICIS using local parameters (i.e. maximum linear power, departure from nucleate boiling ratio). Such engineering solution will be implemented by safety system software-hardware (PTK-Z) on the basis of signals coming from in-core neutron flux detectors, temperature sensors, primary coolant flow and coolant pressure transducers. Calculated survey of possibility to use Kalman filters or corrective filter to eliminate time delay in SPND signals was carried out. The inaccuracy in the method of maximum linear power monitoring was determined. This work shows that the solution was found using the practice of in-core instrumentation, and ICIS designing and operation with improved metrology, reliability and time parameters and using advanced data communication technologies intended for important challenges of the world market, and as a response to standards.
\end{abstract}

\section{INTRODUCTION}

Realisation of protection function on the basis of local parameters is ensured by the following factors in reactor V-412:

- arrangement of ICIDs within the core, 54 in number, each of them being supplied with seven Rhodium SPNDs, with certain time transient characteristics;

- arrangement of coolant temperature sensors in cold legs, coolant flow detectors in the primary loops, and pressure transducers above the core;

- development and implementation of instrumentation equipment, which satisfies safety category 2 requirements (category indication $2 \mathrm{NU}$ as per [1], and 2NU/K2 as per [2]) for quality, velocity and metrology parameters of monitors or system responses, and software, using advanced data communication technologies intended for important challenges of the world market, and with satisfaction of IEC 880, IEC 987 standards and normative documentation requirements for category $2 \mathrm{NU}$ (as per [1]) hardware and software.

\section{FORMULATION OF THE PROBLEM}

The technical solution of local protection system for the V-412 core should provide the following:

- automatic generation of protection signals and delivery to CPSE at reactor power ranging within 20 and $110 \%$ of nominal power in case if the local rod power exceeds the rated limit, or departure of nucleate boiling ratio drops below the rated limited value with time delay at least $3 \mathrm{~s} \mathrm{[3]}$;

- probability of failure to respond a scram function of PTK-Z should not exceed $5 \cdot 10^{-7}$ within a 1 year time domain [4];
- inaccuracy of maximal value of linear fuel rod power density should not exceed $\pm 5 \%[3,5]$;

- inaccuracy of minimal value of departure from nucleate boiling ratio should not exceed $\pm 17 \%[3,6]$.

The objective of this paper is to survey the possibility to integrate in ICIS (PTK-Z) of such function as automatic core protection of reactor $\mathrm{V}-412$ in response to local parameters (i.e. maximum linear power, departure from nucleate boiling ratio) during normal operation and transient conditions.

\section{ARRANGEMENT OF INSTRUMENTATION EQUIPMENT AND COMPUTER FACILITIES}

In order to perform the function of automatic protection in response to local parameters (scram, PP) the following apparatus should be used: instrumentation equipment and computer facilities of safety category 2 (category indication $2 \mathrm{NU}$ as per [1] and $2 \mathrm{NU} / \mathrm{K} 2$ as per [2]), which is integrated in every safety channel of the plant as a part of safety system software-hardware (PTK-Z).

Every PTK-Z cabinet is connected with thermal engineering detectors with cable lines of an individual safety channel. The cable lines deliver every detector signal to instrumentation equipment inlet, and also the signals from 1/6 part of the whole number of SPNDs.

Cabinets PTK-Z and cabinets of various safety categories are furnished with connection via local net of lower level of safety category 2 (category indication $2 \mathrm{NU}$ as per [1] and $2 \mathrm{NU} / \mathrm{K} 2$ as per [2]). This enables every safety channel processor taking decisions using the whole amount of data on in-core processes and deliver protection signal to CPSE of the applicant safety channel. PTK-Z block scheme is given in Fig. 1. 


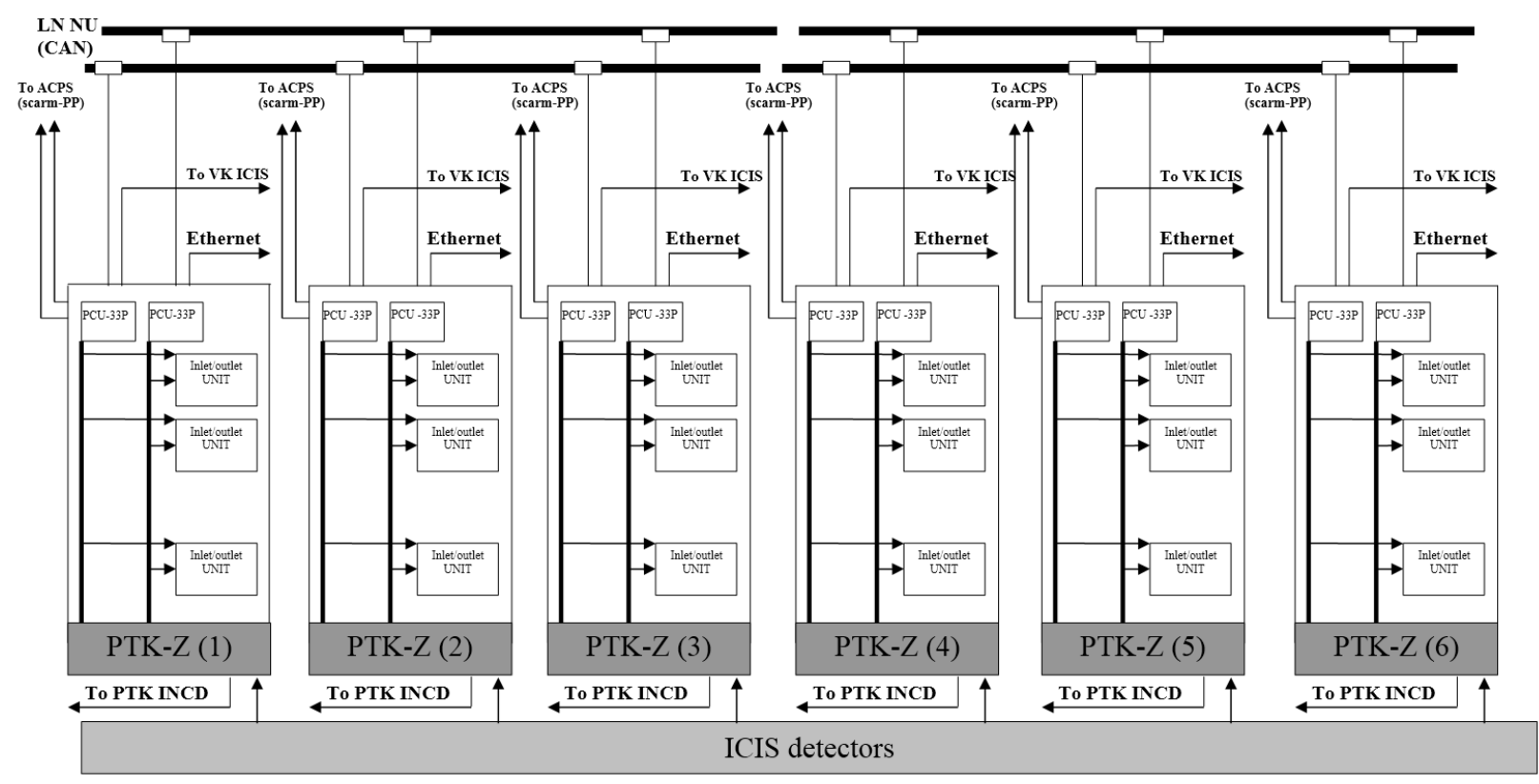

Fig. 1. PTK-Z scheme

\section{SIGNAL INTERPRETATION ALGORITHMS}

\section{Preliminary signal interpretation}

Every delivered analogue signal shall pass a rejection process, which consists of comparing the signal against limitations established [5]:

$$
\mathrm{A}_{\text {min }} \leq \mathrm{A} \leq \mathrm{A}_{\text {max }},
$$

where $A$ is the current signal indication; $A_{\min }-$ is an extremely small design signal indication; $A_{\max }-$ is an extremely large design signal indication.

After a rejection procedure every signal, except SPND signals, should pass a smoothing procedure in accordance with the following formula:

$$
A_{c}(t)=k_{c} \cdot\left[A(t)-A_{c}(t-1)\right]+A_{c}(t-1),
$$

where $A$ is a signal indication; $A_{c}-$ is a smoothed signal indication; $\mathrm{t}$ - denotes a current polling cycle; $(\mathrm{t}-1)$ denotes a previous polling cycle; $k_{c}-$ is an individual smoothing coefficient $\left(0.1 \leq \mathrm{k}_{\mathrm{c}} \leq 1\right)$.

The value of $k_{c}$ depends on the magnitude and character of electromagnetic induction at signal transfer lines from the detectors to the equipment of certain power units, and it can be determined at CA stage.

\section{Interpretation of normalised signals from the}

\section{transducers of general process measurements}

The transducers of general process measurements comprise pressure and pressure difference transducers, detector of boron acid concentration, RCPS capacity sensor, etc. The normalised signals from these detectors are converted into physical units of measurement according to the following formula:

$$
\mathrm{W}=\frac{\mathrm{W}_{\text {up }}-\mathrm{W}_{\text {low }}}{\mathrm{A}_{\text {up }}-\mathrm{A}_{\text {low }}} \cdot\left(\mathrm{A}-\mathrm{A}_{\text {low }}\right)+\mathrm{W}_{\text {low }},
$$

where $\mathrm{A}$ - is the value of normalised signal $(\mathrm{mA}$ or $\mathrm{V})$; $\mathrm{W}_{\text {up }}$ - is the upper margin of normalised signal values (in physical units of measurement); $A_{\text {up }}$ - is the upper margin of normalised signal $(\mathrm{mA}$ or $\mathrm{V}) ; \mathrm{W}_{\text {low }}-$ is the lower margin of normalised signal (in physical units of measurement); $A_{\text {low }}$ - is the lower margin of normalised signal $(\mathrm{mA}$ or $\mathrm{V})$.

\section{Algorithm of determining a fuel rod linear power density and generating a protection signal on the basis of this parameter}

The value of maximum linear power in an (i,j)-th part of the core is determined by a statistical summarising (averaging) of linear power values, which were determined from the signals of six SPNDs of the most close ICID that belong to various PTK-Z channels, where $\mathrm{j}$ is FA No according to the map of core. Correspondence between $j$-th FA and $j(n)$-th ICID in each FA is shown in (Table 1) (the Table gives the Nos. of FAs. with ICID, the distance between ICID and applicable FA is given in the brackets) [5].

List of six FAs located in the close vicinity of ICID and used for power density calculation in every FA

\begin{tabular}{|c|c|c|c|c|c|c|}
\hline FA No & Channe 1 & Channe 2 & Channe 3 & Channe 4 & Channe 5 & Channe 6 \\
\hline 1 & $10(2)$ & $16(4)$ & $30(4)$ & $12(4)$ & $2(2)$ & $18(2)$ \\
\hline 2 & $10(2)$ & $16(5)$ & $30(4)$ & $12(4)$ & $2(0)$ & $5(3)$ \\
\hline$\ldots$ & $\ldots$ & $\ldots$ & $\ldots$ & $\ldots$ & $\ldots$ & $\ldots$ \\
\hline 162 & $158(4)$ & $163(1)$ & $160(2)$ & $148(4)$ & $145(2)$ & $153(2)$ \\
\hline 163 & $158(5)$ & $163(0)$ & $147(3)$ & $148(4)$ & $145(2)$ & $136(4)$ \\
\hline
\end{tabular}


SPND numbering in ICID corresponds to elevation numbering in FA (Fig. 2).

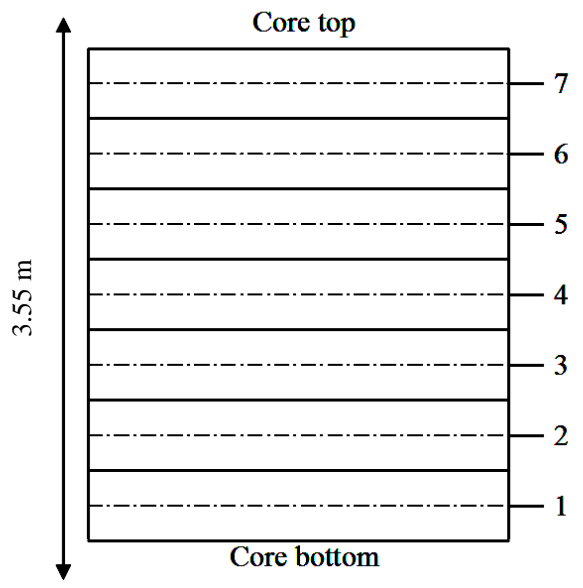

Fig. 2. Core levels whose geometrical centres (from 1-st to 7 -th) correspond to SPND emitters $(1,2, \ldots 7)$

Statistical summarising (averaging) for the neighbouring SPND is performed according to the following formula:

$$
\overline{\mathrm{A}}_{\mathrm{ij}}=\frac{\mathrm{KK}_{\mathrm{ij}}}{311} \cdot \frac{\sum_{\mathrm{n}=1}^{6} \mathrm{q}_{\mathrm{ijj_{n }}} \cdot \eta_{\mathrm{ij}_{\mathrm{n}}} \cdot \frac{\mathrm{KV}_{\mathrm{ij}} \cdot \mathrm{J}_{\mathrm{ij}_{\mathrm{n}}} \cdot \lambda_{\mathrm{ij}_{\mathrm{n}}}}{\mathrm{KV}_{\mathrm{ij}} \cdot \mathrm{Kc}_{\mathrm{ij} \mathrm{j}_{\mathrm{n}}}}}{\sum_{\mathrm{n}=1}^{6} \mathrm{q}_{\mathrm{ijj}} \cdot \eta_{\mathrm{ij} \mathrm{j}_{\mathrm{n}}}},
$$

where $\mathrm{KK}_{\mathrm{ij}}$ - is a linear power peaking factor of the (i,j) section of the core; $\mathrm{Kc}_{\mathrm{jn}}$ - is a mean linear power peaking factor of six fuel rods surrounding a tube with ICID in the $(i, j)$ section of the core; $\mathrm{KV}_{\mathrm{ij}}-$ is relative power density of the $(i, j)$ section of the core; $K_{\mathrm{ijn}}$ - is relative power density in $\mathrm{n}$ SPND location associated with $(i, j)$ section of the core; $j_{n}-$ are ICID Nos. that surround $j$-th FA $(n=1 \ldots 6) ; \lambda_{i_{n}}-$ is the sensitivity of $i-$ the SPND in the $\mathrm{j}_{\mathrm{n}}$-th ICID converted into the unit of FA length measurement; $\eta_{i_{\mathrm{n}}}-$ is the sign of $\left(i, j_{n}\right)$ SPND availability; $J_{i_{\mathrm{n}}}$-is normalised $F$ current of $i$ SPND in $\mathrm{j}_{\mathrm{n}}$ ICID; $\mathrm{q}_{\mathrm{ij}_{\mathrm{jn}}}$ - is statistical weight of $\mathrm{jn}$ SPND signal in calculation of linear power density in ij section of the core.

$\mathrm{q}_{\mathrm{ij} \mathrm{jn}}$ shall be originally determined according to formula:

$$
\mathrm{q}_{\mathrm{ijj} \mathrm{n}_{\mathrm{n}}}=\frac{\mathrm{F}(\mathrm{r})}{\mathrm{F}(\mathrm{o})},
$$

where $F(r)$ is a relative value of "influence function" at distance $r$ from the centre of $(j)$ th FA to location of $j_{n}$ th SPND at i level; $F(0)$ is a relative value of "influence function" in the centre of $j$-th FA.

Correspondence of statistical weights to the distance between ICID and FA is given in Table 2 .

Relative power density 3-dimensional in core distributions are gained during power density recovery process in VK ICIS. Power density recovery algorithm in based on mathematical model including equation of connection between the results of measurements and the field to be found, and also the neutron diffusion equation. To work out the diffusion equation and definition neutron-physical model parameters the iteration method is used. To decrease deviation between neutron-physical model and transducer signals adaptation of material parameter and division section, based on measurement results is carried out. Described algorithm has been used in MCDS PPO and has successful operation experience over 100 reactor-years.

Table 2

Correspondence between statistical weight and distance between ICID and FA

\begin{tabular}{|c|c|}
\hline Distance between ICID and FA & Statistical weight \\
\hline 0 & 1 \\
\hline 1 & 0.2954 \\
\hline 2 & 0.1336 \\
\hline 3 & 0.1024 \\
\hline 4 & 0.0554 \\
\hline 5 & 0.005 \\
\hline
\end{tabular}

For the purpose of calculation accuracy of fuel rod linear power density and reliability of protection signal, which generates on the basis of this parameter, also taking into account the probability of uncontrolled CPS CR movement, the value of maximum linear power of FA that contains working group CPS CR in $(i, j)$ section of the core is determined on the basis of duplicated statistical summarising according to the following formula:

$$
\overline{\mathrm{A}}_{\mathrm{ij}}^{\prime \prime}=\frac{\mathrm{KK}_{\mathrm{ij}}}{311} \cdot \frac{\sum_{\mathrm{lj}=0}^{6} \mathrm{KV}_{\mathrm{ij}} \cdot \overline{\mathrm{KV}}_{\mathrm{ilj}} \cdot \mathrm{q}_{\mathrm{ijlj}}}{\sum_{\mathrm{lj}=0}^{6} \mathrm{KV}_{\mathrm{ilj}} \cdot \mathrm{q}_{\mathrm{ijj}}},
$$

where $\mathrm{KV}_{\mathrm{ilj}}$ - is the value of relative power density calculated on the basis of formula:

$$
\overline{\mathrm{KV}}_{\mathrm{ilj}}=\frac{\overline{\mathrm{A}}_{\mathrm{ilj}}}{\mathrm{KK}_{\mathrm{ilj}}} \cdot 311 \text {, }
$$

where $\overline{\mathrm{A}}_{\mathrm{ilj}}$ - is the magnitude to be determined using formula (4) for every $F A$ neiboughring the $j \mathrm{FA}$ $\left(\mathrm{l}_{\mathrm{j}}=0, \ldots 6\right)$, if $\mathrm{l}_{\mathrm{j}}=0 \mathrm{Kv}_{\mathrm{ilj}}=\mathrm{Kv}_{\mathrm{ij}}$.

In the base condition, arrays $\mathrm{KK}, \mathrm{Kc}, \mathrm{KV}, \lambda$, and $\eta$ are periodically delivered from VK ICIS and ensure online monitoring maximum linear power by way of online measuring of SPND currents.

The acquired $\overline{\mathbf{A}}_{\mathrm{ij}}$ values are compared against the design limitations (PP, scram), which are individual for every axial core section.

Should a design limitation is achieved or exceeded at any of the core sections, an applicable protection signal shall be sent to scram - PP system

The process of preparation, verification and display of the above mentioned magnitudes to PTK-Z is called calibration of protection system instrumentation channels on the basis of local parameters, which is required for sustaining ICIS metrology characteristics at applicable level within a considered function.

In order to use calibration data it is required to write formula 30 anew in the following format:

$\overline{\mathrm{A}}_{\mathrm{ij}}(\mathrm{t})=\frac{\mathrm{KK}_{\mathrm{ij}}(0)}{311} \cdot \frac{\sum_{\mathrm{n}=1}^{6} \mathrm{q}_{\mathrm{ij}_{\mathrm{n}}} \cdot \eta_{\mathrm{ij}_{\mathrm{n}}} \cdot \frac{\mathrm{KV}_{\mathrm{ij}}(0) \cdot \mathrm{J}_{\mathrm{ij}}(\mathrm{t}) \cdot \lambda_{\mathrm{ij} \mathrm{n}}(0)}{\mathrm{KV}_{\mathrm{ij}\left(\mathrm{n}_{\mathrm{in}}\right)}(0) \cdot \mathrm{Kc}_{\mathrm{ij}}(0)}}{\sum_{\mathrm{n}=1}^{6} \mathrm{q}_{\mathrm{ij}} \cdot \eta_{\mathrm{ij}_{\mathrm{n}}}}$, 
and formula (6) in the following format:

$$
\overline{\mathrm{A}}_{\mathrm{ij}}^{\prime \prime}=\frac{\sum_{\mathrm{i}=0}^{6} \overline{\mathrm{A}}_{\mathrm{ijj_{j }}} \cdot \mathrm{q}_{\mathrm{ij} \mathrm{j}_{\mathrm{j}}}}{\sum_{\mathrm{l}=0}^{6} \mathrm{q}_{\mathrm{ij} \mathrm{j}_{\mathrm{j}}}}=\frac{\mathrm{KK}_{\mathrm{ij}}(0)}{311} \frac{\sum_{\mathrm{i}_{\mathrm{j}}=0}^{6} \frac{\mathrm{KV}_{\mathrm{ij}}(0) \cdot \overline{K V}_{\mathrm{ij} \mathrm{j}_{\mathrm{j}}}(\mathrm{t})}{\mathrm{KV}_{\mathrm{ij} \mathrm{j}_{\mathrm{j}}}(0)} \cdot \mathrm{q}_{\mathrm{ij} \mathrm{j}_{\mathrm{j}}}}{\sum_{\mathrm{i}=0}^{6} \mathrm{q}_{\mathrm{ij} \mathrm{j}_{\mathrm{j}}}},
$$

where $1_{j}$ are the numbers of FAs adjacent to the $j$-th FA if $\mathrm{l}_{\mathrm{j}}=0, \mathrm{l}_{\mathrm{j}}=\mathrm{j}$.

All the coefficients and magnitudes, except $J_{i_{n}}(t)$, are valid for the time when calibration was performed.

Algorithm for calculation of minimal value of departure from nucleate boiling ratio and generating a protection signal on the basis of this parameter

The aggregate coolant mass flow $\mathrm{G}^{1 \mathrm{~K}}$ in the primary loops is calculated by the following formula $[5,6]$ :

$$
\mathrm{G}^{1 \mathrm{~K}}=\sum_{\mathrm{k}=1}^{4} \mathrm{G}_{\mathrm{k}},
$$

where $G_{k}$ is the coolant mass flow in k-th loop.

An average water mass velocity in FA cell ( $\rho w)$ is calculated using the following formula:

$$
\rho \mathrm{w}=\frac{\mathrm{G}^{1 \mathrm{~K}} \cdot\left(1-\mathrm{K}_{\text {leak }}\right)}{163 \cdot \mathrm{F}_{\mathrm{FA}}} \cdot \mathrm{K}_{\text {peak }},
$$

where $\mathrm{K}_{\text {leak }}$-is a coefficient that accounts coolant leakages; $F_{\mathrm{FA}}=0.0246 \mathrm{~m}^{2}-$ is the area of FA cross section without central channel and channels for AR; $\mathrm{K}_{\text {peak }}=0.98-$ is a coefficient that accounts the mass velocity peaking along FA cross section.

For every FA, the coolant inlet temperature is determined using the following formula:

$$
\mathrm{T}_{\mathrm{j}}^{\mathrm{inl}}=\frac{\sum_{\mathrm{k}=1}^{4} \mathrm{~T}_{\mathrm{k}}^{\mathrm{c}} \cdot \mathrm{G}_{\mathrm{k}} \cdot \mathrm{P}_{\mathrm{kjm}} \cdot \mathrm{F}_{\mathrm{k}}}{\sum_{\mathrm{k}=1}^{4} \mathrm{G}_{\mathrm{k}} \cdot \mathrm{P}_{\mathrm{kjm}} \cdot \mathrm{F}_{\mathrm{k}}},
$$

where $\mathrm{j}$ - FA No; $\mathrm{T}_{\mathrm{k}}^{\mathrm{c}}$ - is coolant temperature in cold leg of k-th loop; $F_{k}$ - is the sign of RCPS actuation in $\mathrm{k}$-th loop; $\mathrm{G}_{\mathrm{k}}$ - is coolant flow in $\mathrm{k}$-th loop; $\mathrm{m}-$ is a code making $\mathrm{F}_{1} \cdot 8+\mathrm{F}_{2} \cdot 4+\mathrm{F}_{3} \cdot 2+\mathrm{F}_{4} ; \mathrm{P}_{\mathrm{kjm}}-$ is a coefficient of $\mathrm{k}$ loop temperature influence on the temperature of $j$ the FA with $m$-th condition of values of signs $\mathrm{F}_{\mathrm{k}}$.

For each selected core section $(i, j)$, enthalpy $I_{i j}$ is calculated according to the following formula:

$$
\mathrm{I}_{\mathrm{ij}}=\frac{\frac{\mathrm{H}_{\mathrm{c}}}{8} \cdot\left(\frac{\overline{\mathrm{A}}_{\mathrm{lj}}}{8}+\sum_{\mathrm{n}=1}^{\mathrm{i}-1} \overline{\mathrm{A}}_{\mathrm{nj}}+\frac{\overline{\mathrm{A}}_{\mathrm{ij}}}{2}\right) \cdot 10^{6} \cdot \frac{1}{3}}{\rho \mathrm{w} \cdot \mathrm{F}_{\text {cell }}} \cdot \mathrm{K}_{\mathrm{t}}+\mathrm{I}_{\mathrm{i}}^{\mathrm{inl}},
$$

where $\mathrm{K}_{\mathrm{t}}-\mathrm{K}_{\mathrm{t}}$ is margin coefficient in preheating; $\mathrm{I}_{\mathrm{i}}^{\mathrm{inl}}=\mathrm{I}\left(\mathrm{P}_{\mathrm{inl}}, \mathrm{T}_{\mathrm{i}}^{\mathrm{inl}}\right) ; \mathrm{H}_{\mathrm{c}}-$ is the core height; $\mathrm{P}_{\mathrm{inl}}-$ is inlet pressure in the core; $\mathrm{F}_{\text {cell }}$ - is the area of cross section of the cell under consideration.

For each selected core section $(i, j)$ relative enthalpy $\mathrm{X}_{\mathrm{ij}}$ is calculated in accordance with the following formula:

$$
X_{i j}=\frac{I_{i j}-I^{\prime}\left(P_{i n l}\right)}{r\left(P_{i n l}\right)},
$$

where $I^{\prime}\left(P_{\text {inl }}\right)$ - is water enthalpy in saturation line; $r\left(P_{i n l}\right)$ - is specific heat of vaporisation.

For each selected core section $(i, j)$ the value $\varphi 5$ ) critical heat flux $Q_{i j}^{c r i}$ is calculated using the following formula:

$$
\begin{aligned}
& \mathrm{Q}_{\mathrm{ij}}^{\mathrm{cri}}=\mathrm{f}_{\mathrm{F}} \cdot 0.795 \cdot\left(\left(1-\mathrm{X}_{\mathrm{ij}}\right)^{0.105 \cdot \operatorname{Pinl}-0.5}\right) \times \\
& \times(\rho \mathrm{w})^{0.311 \cdot(1-\mathrm{Xij})-0.127} \cdot\left(1-0.0185 \cdot \mathrm{P}_{\mathrm{inl}}\right),
\end{aligned}
$$

where $f_{F}-$ is form factor calculated by formula:

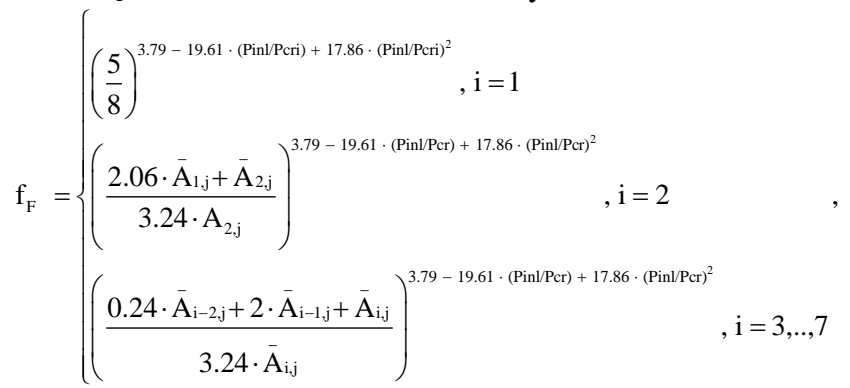

where $\mathrm{P}_{\mathrm{inl}}=22.115 \mathrm{MPa}$ is critical water pressure.

Departures from nucleate boiling ratio $\left(\mathrm{DNB}_{\mathrm{ij}}\right)$ are determined according to formula:

$$
\mathrm{DNB}_{\mathrm{ij}}=\frac{\mathrm{Q}_{\mathrm{ij}}^{\mathrm{cri}} \cdot \pi \cdot \mathrm{d} \cdot\left(1-\mathrm{K}_{\mathrm{f}}\right)}{\overline{\mathrm{A}}_{\mathrm{ij}} \cdot \mathrm{K}_{\mathrm{q}}},
$$

where $K_{f}-$ is the error of formula for critical heat flux; $\mathrm{K}_{\mathrm{q}}-$ is margin coefficient for power; $\pi=3.1416$; $\mathrm{d}=0.0091 \mathrm{~m}-$ is fuel rod diameter.

From all the obtained $\mathrm{DNB}_{\mathrm{ij}}$ values the smallest $\mathrm{DNB}_{\text {min }}$ value is selected and compared against the design limitations (PP, scram). Should the design limitation be reached or fall below, an applicable protection alarm signal shall be sent to system PPscram.

\section{INACCURACY CALCULATIONS General description}

The whole set of inaccuracies of local protection system may be split into two parts: dynamic and statistical [5].

Dynamic inaccuracies are defined by:

- Increase velocity of local linear power density, method selected for elimination of time delay of SPND currents and inaccuracy in determining the value of the instant component of SPND signals, which comprise the $\operatorname{system}\left(\sigma_{\mathrm{K}-\mathrm{F}}, \sigma_{\mathrm{F}-\mathrm{K}}\right)$.

- Inaccuracy in determining the instant component $\left(\sigma_{\mathrm{Rh}}\right)$.

- Scope and manner of CPS CR movement within the time period between calibration actions $\left(\sigma_{\mathrm{Kdin}}\right)$.

Allowable difference between current calibration coefficients and those transmitted to PTK-Z $\left(\sigma_{\text {Calibr }}\right)$.

Statistical inaccuracies are defined by:

- Distance between the controlled section and transducer $\left(\sigma_{\kappa}\right)$;

- Inaccuracy of calibration coefficients $\left(\sigma_{\mathrm{VU}}\right)$;

- Inaccuracy of the equipment, which in our case depends on the share of random component of 
inaccuracy in measuring SPND currents, and also by interference and induction on the way of passing a signal from Rhodium SPNDs and methods that are used for their elimination $\sigma_{\text {equp }}$.

Both inaccuracies of tolerance values for fuel production and assembly-to assembly gaps are taken into account in calculation of engineering uncertainty coefficient. The inaccuracy of reactor thermal power is taken into account in calculation of uncertainty coefficient for keeping reactor power. Both the uncertainty coefficient and safety factor are taken into account in calculation of ultimate tolerable values of power density in a certain fuel loading.

\section{Analysis of dynamic inaccuracy}

It is adopted in the system:

- for monitoring the processes with velocities ranging within $4 \%$ per second and $40 \%$ per second to apply a corrective filter;

- for monitoring the processes with velocities ranging within $0.1 \%$ per second and $5 \%$ per second to apply a Kalman filter.

Any of these filters has a $0.6 \mathrm{~s}$ response cycle, emitter diameter of $0.5 \mathrm{~mm}$ (instantaneous component is close to 6\%). The corrective filter is capable to completely eliminate the delay; while Kalman filter is intended to allow a $0.5 \mathrm{~s}$ delay and reduced coefficient of interference elimination.

Investigation proved that:

- corrective filter provides a time delay at $0.05 \mathrm{~s}$ for its range of processes of time changes, and this time delay may be neglected. In this case, the inaccuracy, which comprises the influence of interference and induction, is defined by rejection "gates" and does not exceed $\pm 4 \%$;

- Kalman filter, provides a time delay at $0.5 \mathrm{~s}$ for its range of processes of time changes, and this time delay may be also neglected. In this case, the inaccuracy, which comprises the influence of interference and induction, is defined by rejection "gates" and does not exceed $\pm 1 \%$.

A complimentary time difference, caused by a probable uncertainty of instantaneous component ranging within $\pm 17 \% \quad(c=(6 \pm 1) \%$ ), (for instance, the filter is adjusted for an instantaneous component of $6 \%$, while SPND has a $5 \%$ instantaneous component), has the value of $\pm 0.05 \mathrm{~s}$ for a corrective filter and for Kalman filter $\pm 0.5 \mathrm{~s}$. This brings to additional maximal errors: for corrective filter at most $\pm 2 \%$, for Kalman filter at most $\pm 2.5 \%$, respectively.

For instance, Figs. 3 and 4 depict the reaction of lagging behind of a corrective filter with fluctuation of neutron flux velocity of $40 \%$ per second. In this case, the coefficients of the filter were adjusted for the instantaneous component of $6 \%$, while the actual instantaneous component of SPND was 5\%. Fig. 5 depicts the reaction of lagging behind of Kalman filter with fluctuation of neutron flux velocity of $5 \%$ per second.

In this case, the coefficients of the filter were adjusted for the instantaneous component of $6 \%$, while the actual instantaneous component of SPND was $5 \%$.

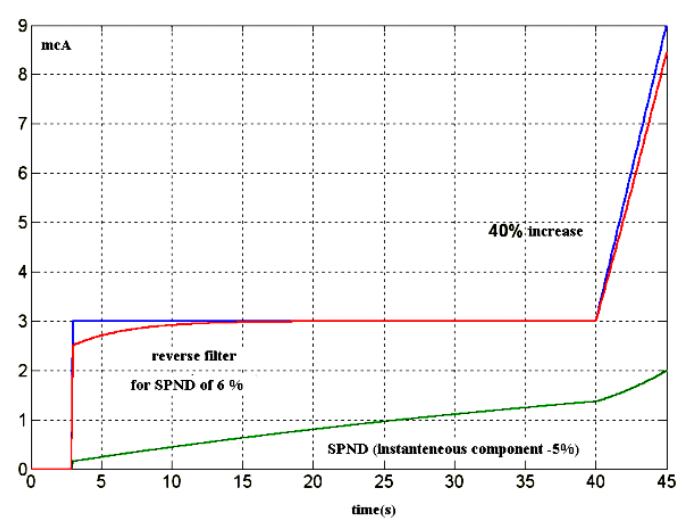

Fig. 3. Influence of incorrect accounting the instantaneous component upon the increase of corrective filter lagging behind

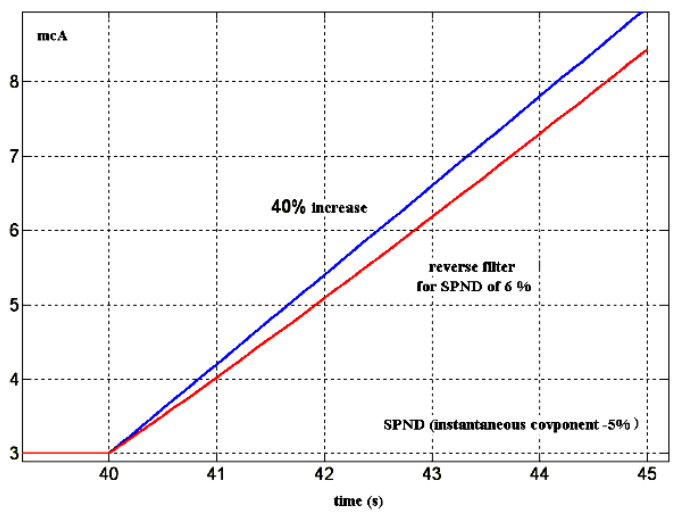

Fig. 4. Part of the fig. 3: influence of incorrect accounting the instantaneous component upon the increase of corrective filter lagging behind

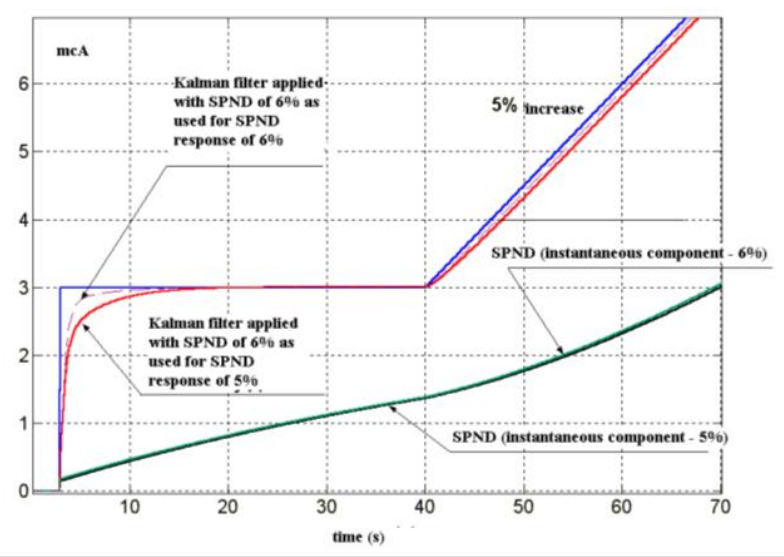

Fig. 5. Influence of incorrect accounting the instantaneous component upon the increase of Kalman filter lagging behind

The error discussed herein actually has a significantly smaller value, because the tolerance values for variance in diameters of Rhodium wire are small.

Thus, the aggregate dynamic inaccuracy:

- for corrective filter does not exceed: $\sigma_{D I N_{K-F}}=\sqrt{\left(\sigma_{K-F}\right)^{2}+\left(\sigma_{R h}\right)^{2}}=\sqrt{(4 \%)^{2}+(2 \%)^{2}} \leq 4.5 \%$;

- for Kalman filter does not exceed: $\sigma_{D I N_{F-K}}=\sqrt{\left(\sigma_{F-K}\right)^{2}+\left(\sigma_{R h}\right)^{2}}=\sqrt{(1 \%)^{2}+(2.5 \%)^{2}} \leq 2.7 \%$, and for the processes with velocities less than $1 \%$ per second Kalman filter inaccuracy may be neglected. 


\section{Initial data. Core loading}

This investigation simulated the first fuel loading of NPP with V-412 reactor [5]. The calculations were based on the map of fuel loading, which is shown in Fig. 6.

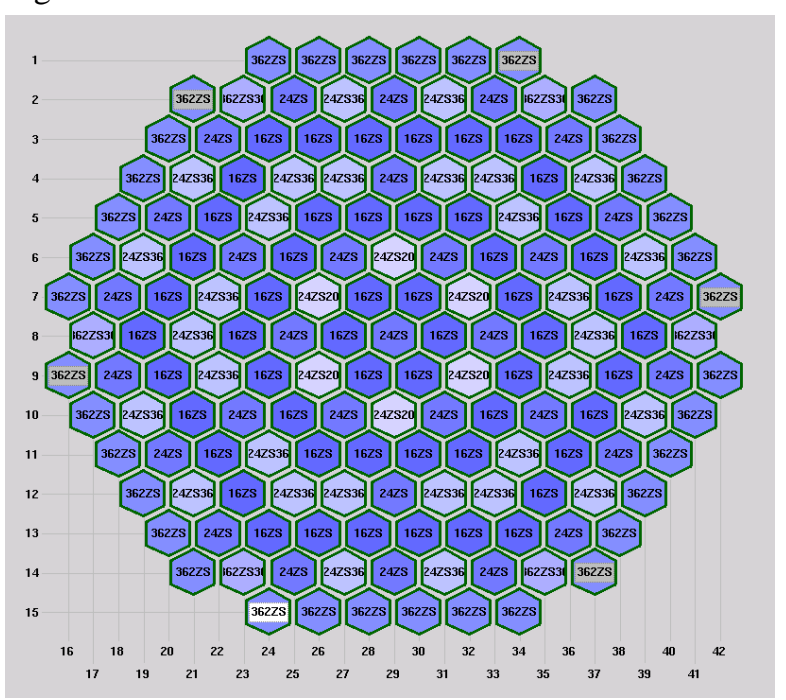

Fig. 6. Map of the first fuel loading of NPP with V-412 reactor

Description of fuel types is given in Table 3

Table 3

Description of fuel types

\begin{tabular}{|c|c|}
\hline Fuel type & Description \\
\hline $16 \mathrm{ZS}$ & $1.6 \%$ \\
\hline $24 \mathrm{ZS}$ & $2.4 \%$ \\
\hline $362 \mathrm{ZS}$ & $3.62 \%(3.7+3.3)$ \\
\hline $24 \mathrm{ZS} 36$ & $2.4 \%, \mathrm{~B}-0.036$ \\
\hline $24 \mathrm{ZS} 20$ & $2.4 \%, \mathrm{~B}-0.020$ \\
\hline $362 \mathrm{ZS} 36$ & $3.62 \%, \mathrm{~B}-0.036$ \\
\hline
\end{tabular}

CPS CR distribution withi $\mathrm{n}$ the group is given in Table 4.

Table 4

FAs containing CPS CR and CPS CR distribution within the groups

\begin{tabular}{|c|c|}
\hline $\begin{array}{c}\text { Group } \\
\text { No }\end{array}$ & FAs containing CPS CR \\
\hline 1 & $13 ; 74 ; 147 ; 151 ; 90 ; 17 ; 20 ; 46 ; 113 ; 144 ; 118 ; 51$ \\
\hline 2 & $44 ; 85 ; 123 ; 120 ; 79 ; 41 ; 9 ; 24 ; 101 ; 155 ; 140 ; 63$ \\
\hline 3 & $21 ; 59 ; 125 ; 143 ; 105 ; 39 ; 68 ; 69 ; 81 ; 83 ; 95 ; 96$ \\
\hline 4 & $111 ; 121 ; 93 ; 53 ; 43 ; 71$ \\
\hline 5 & $98 ; 122 ; 107 ; 66 ; 42 ; 57$ \\
\hline 6 & $22 ; 73 ; 136 ; 142 ; 91 ; 28$ \\
\hline 7 & $19 ; 34 ; 100 ; 145 ; 130 ; 64 ; 110 ; 80 ; 56$ \\
\hline 8 & $11 ; 47 ; 126 ; 153 ; 11738 ; 84 ; 108 ; 54$ \\
\hline 9 & $87 ; 146 ; 141 ; 141 ; 77 ; 18 ; 23 ; 82$ \\
\hline 10 & $52 ; 58 ; 133 ; 31 ; 112 ; 106$ \\
\hline
\end{tabular}

Group 10 is a control one.

Coolant flow in the core is $84000 \mathrm{~m}^{3} / \mathrm{h}$.

Pressure below the core -157 bar.

Inlet coolant temperature in the core $-291^{\circ} \mathrm{C}$

Position of CPS CR working group (No 10). From the core bottom is $90 \%(318.6 \mathrm{~cm})$ (with burnup simulation).

Effective boundary conditions for delayed neutrons:

in a radial reflector are $24 \mathrm{~cm}$;

in an edge reflector are $27 \mathrm{~cm}$.

\section{Condition variety}

The conditions for the beginning and end of cycle life have been investigated for exhausting the reactivity margin ion boron, with various positions of CPS CR groups and certain clusters. The condition parameters are shown in table (Table 5).

Table 5

Parameters of conditions under investigation

\begin{tabular}{|c|c|c|c|c|c|c|c|c|c|c|}
\hline \multirow{2}{*}{$\begin{array}{l}\text { Condition } \\
\text { No }\end{array}$} & \multirow{2}{*}{$\begin{array}{l}\text { Cycle } \\
\text { moment } \\
\text { (EFPD) }\end{array}$} & \multirow{2}{*}{$\begin{array}{l}\text { Mreactor } \\
\text { power }\end{array}$} & \multirow{2}{*}{$\begin{array}{c}\mathrm{H}_{3} \mathrm{BO}_{3} \\
\text { comcentration }\end{array}$} & \multicolumn{3}{|c|}{$\begin{array}{l}\text { Position of CR CPR } \\
\text { group }\end{array}$} & \multirow{2}{*}{$\begin{array}{l}\text { RCU group } \\
\text { position }\end{array}$} & \multirow{2}{*}{$\begin{array}{c}\text { No. of FA } \\
\text { with a stuck } \\
\text { CPS CR }\end{array}$} & \multirow{2}{*}{$\begin{array}{c}\text { Position of } \\
\text { a stuck CPS } \\
\text { CR }\end{array}$} & \multirow{2}{*}{$\begin{array}{c}\text { Data table } \\
\text { No }\end{array}$} \\
\hline & & & & 8 -th & 9-th & 10-th & & & & \\
\hline 1 & 0 & $100 \%$ & critical & $100 \%$ & $100 \%$ & $90 \%$ & $100 \%$ & 100 & $40 \%$ & 7 \\
\hline 2 & 0 & $100 \%$ & critical & $100 \%$ & $100 \%$ & $40 \%$ & $100 \%$ & - & - & 8 \\
\hline 3 & 293.7 & $100 \%$ & 0 (subcrit.) & $100 \%$ & $100 \%$ & $90 \%$ & $100 \%$ & 100 & $40 \%$ & 9 \\
\hline 4 & 293.7 & $100 \%$ & 0 (subcrit.) & $100 \%$ & $100 \%$ & $40 \%$ & $100 \%$ & - & - & 10 \\
\hline
\end{tabular}

For every condition there have been performed the diagrams that depict the dependence of inaccuracy in determining the maximum linear power in protection system that uses local parameters upon the margin to design limits. The diagrams show the variety of data points covering the entire core space. The diagrams reveal a common trend of growth of the inaccuracy value with the increase of margin to design limitations, and also a drop of the inaccuracy value with linear power values close to the margins or exceeding the margins (the margin to the setpoint becomes negative). BIPR-7A [7] and Permak-A [8, 9] calculations were performed for 10 axial elevations.

\section{Main findings}

Every finding without any exclusion prove that:

- methodological inaccuracies in monitoring of maximum linear power in the core space, which is free from CPS CR (in the base design condition of V-412 reactor unit this makes $99.6 \%$ of the core space), do not exceed $\pm 2 \%$;

- the above stated methodological inaccuracy for the FA length were absorbers CPS CR are emerged, significantly grows (up to 20\%), meanwhile, the margin to design limitations grows even more significantly (up to $40 . .50 \%$ ) and, consequently, this phenomenon does not make an obstacle for the local parameter protection system to perform the design base functions.

Figures (Figs. 7-14) depict the dependence of methodological inaccuracies in monitoring the maximum linear power upon the margin to the design limitation with account of single failure criterion in every individual PTK-Z semi set. The data is given for both the beginning and end of fuel cycle for reactor base operation with sticking of individual CPS CR and with changing the CPS CR position up to $40 \%$ from the core bottom. In these figures it is necessary to point out a 
high concentration of calculation data (7987 data points) acquired during investigation of methodological inaccuracies of this algorithm. Each of the figures shows the inaccuracy values of maximum linear power, and the comparison data against design limitations.

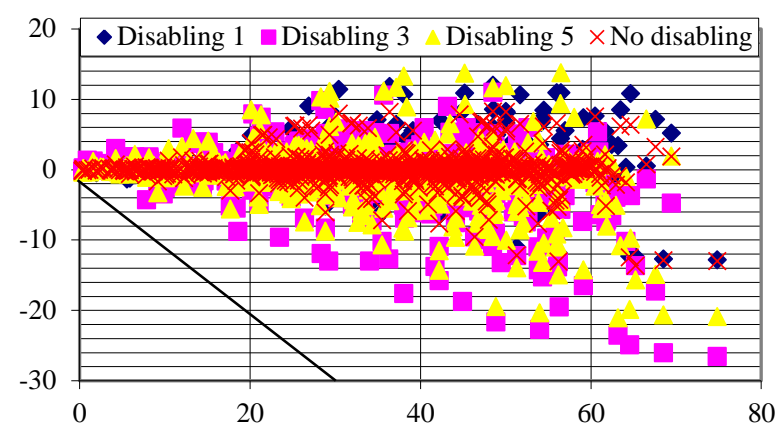

Fig. 7. TEF=0, stuck CPS CR No. 100 at elevation of $40 \%$ from the core bottom, $H 10=90 \%$, calculation made for PTK-Z semi set one

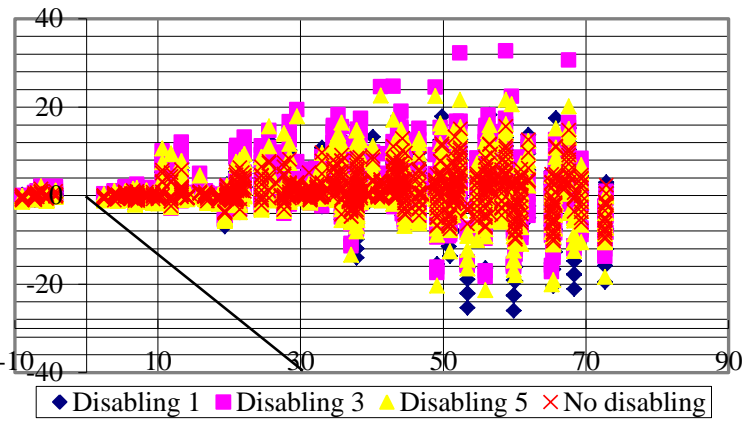

Fig. 8. TEF $=0$, critical condition with location of CPS $C R$ working group at elevation of $40 \%$ from the core bottom, calculation made for PTK-Z semi set one

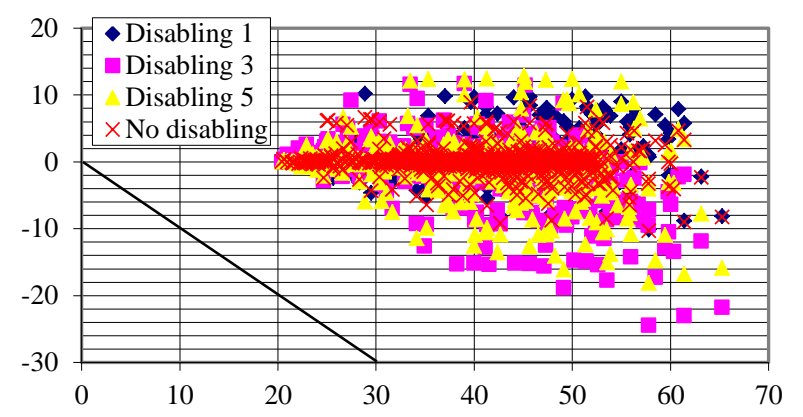

Fig. 9. TEF $=293.7$, stuck CPS CR No. 100 at elevation of $40 \%$ from the core bottom, $H 10=90 \%$, calculation made for PTK-Z semi set one

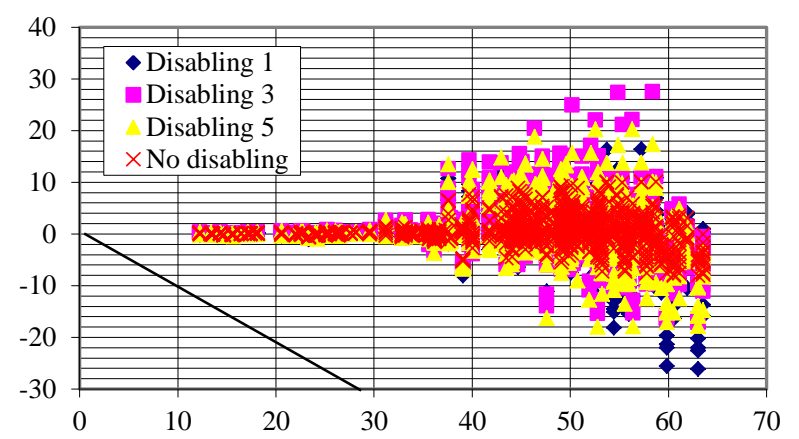

Fig. 10. $T E F=293.7$, condition with location of CPS CR working group at elevation of $40 \%$ from the core bottom, calculation made for PTK-Z semi set one

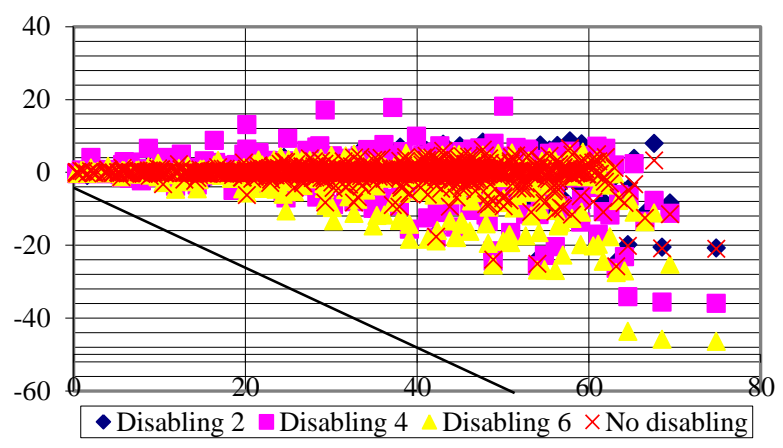

Fig. 11. TEF=0, stuck CPS CR No. 100 at elevation of $40 \%$ from the core bottom, $H 10=90 \%$, calculation made for PTK-Z semi set two

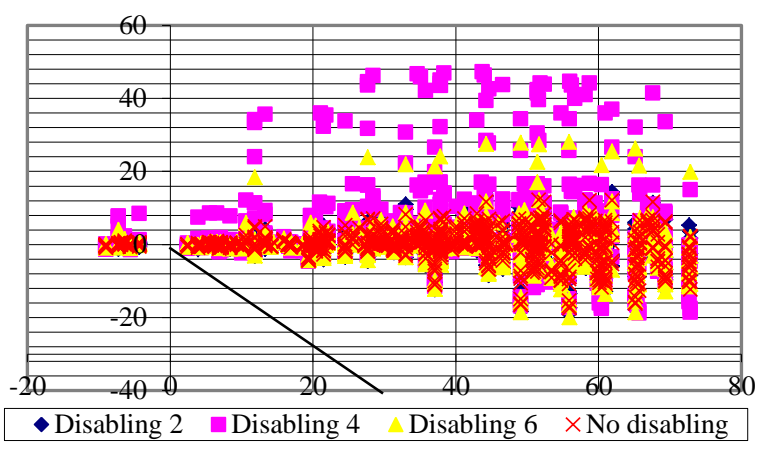

Fig. 12. TEF $=0$, critical condition with location of CPS $C R$ working group at elevation of $40 \%$ from the core bottom, calculation made for PTK-Z semi set two

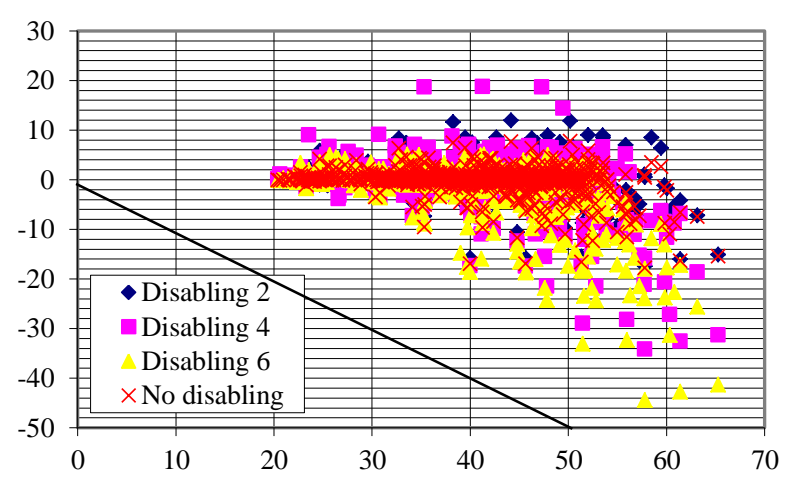

Fig. 13. TEF $=293.7$, stuck CPS CR No. 100 at elevation of $40 \%$ from the core bottom, $H 10=90 \%$, calculation made for PTK-Z semi set two

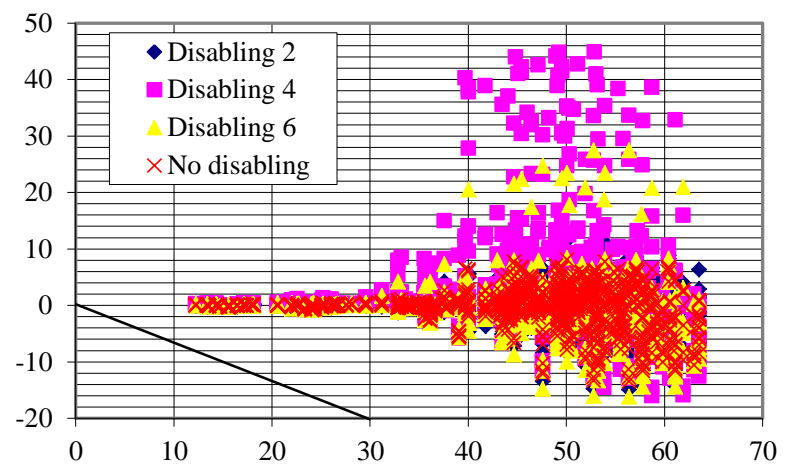

Fig. 14. TEF $=293.7$, condition with location of CPS $C R$ working group at elevation of $40 \%$ from the core bottom, calculation made for PTK-Z semi set two.

Figs. 7, 8, and 11, 12 show the distribution of inaccuracies at the beginning and end of fuel cycle, 
when boron reactivity margin is exhausted ( 0 and 293.7 effective power days), for first and second PTK-Z semi set, respectively. For calibration we selected the state where CR working grop has a position of $90 \%$ from the core bottom.

Figs. 9-14 show the same magnitudes if the position of CPS CR working group changes up to $40 \%$ of the core bottom.

All the eight figures show that all most stressed core sections the inaccuracy values do not exceed the threshold of $1.5 \ldots .2 \%$ with allowance for a single failure criterion.

Figs. 7-14 show the high values of inaccuracy that appear in the locations of CPS CR emerging, disappear in the places where the linear power directly approaches the design limits or exceeds them, which always coincides with CPS CR extraction.

Thus, the investigations performed proved, that:

- additional variable component of the inaccuracy

$\sigma_{\mathrm{Kdin}}$ occurs in the locations of CPS CR submerging and reaches a significant value (up to $30 \%$ ). In such cases the local linear power will always drop, and a margin to design limits, which exceeds the inaccuracy, will inadvertently appear;

- the value approach to design limits is always associated with CPS CR unavailability in controlled core section, which automatically eliminates the additional dynamical component. At the same time methodical inaccuracy in controlled areas, connected with ICID distribution within the core, does not exceed, while inaccuracy, caused by difference between currect calibration coefficients from those transmitted to PTK$\mathrm{Z}$, never exceeds $2 \%$.

\section{Analysis of statistical inaccuracy}

The analysis of inaccuracy, which is caused by the increase of random noise component in the equipment either by a corrective filter, or Kalman filter, proved that the increase of interference of 0.1 or $0.3 \%$ by 20 or 6 times, respectively, can be neglected.

Evaluation of PPO ICIS-M operation at power units NPP has revealed that the error of calibration coefficients $\sigma_{\mathrm{VU}}(\mathrm{MSD})$ comes to $2.5 \%$.

Proceeding from BIPR-7A and PERMAK-A findings, the net value of $\sigma$ accounting a single failure criterion (with failed SPNDs 63 in number - one safety channel) does not exceed $2 \ldots 3 \%$ at reaching design operation limits.

\section{Aggregate inaccuracy}

As a result, the aggregate inaccuracy in monitoring maximum linear power may be written in the following form:

$$
\begin{aligned}
& \sqrt{\sigma^{2}}=\sqrt{\sigma_{V U}^{2}+\sigma_{R h}^{2}+\sigma_{(F-K)^{2}}^{2}+\sigma_{K}^{2}+\sigma_{\text {Calibr }}^{2}}= \\
& =\sqrt{2.25+6.25+1+4+4}=4.2 \% .
\end{aligned}
$$

A conservative evaluation of relative error in the value of departure from nucleate boiling ratio can be determined by the following formula:

$$
\begin{aligned}
& \Delta_{\mathrm{DNB}}=\sqrt{\Delta_{\mathrm{F}}^{2}+\Delta \mathrm{G}_{\mathrm{FA}}^{2}+\Delta \mathrm{T}_{\mathrm{inl}}^{2}+\Delta \mathrm{A}^{2}+\Delta_{\mathrm{pr}}^{2}}= \\
& =\sqrt{15^{2}+3^{2}+3.5^{2}+4.2^{2}+2^{2}} \approx 16.4 \% .
\end{aligned}
$$

where $\Delta_{\mathrm{F}}$-is the error of calculation formula, which makes $15 \% ; \Delta \mathrm{G}_{\mathrm{FA}}$ - is the error in coolant flow in FA, which makes at most $3 \%$ (the error of leakage from the core, and coolant flow peakidness are not taken into account); $\Delta \mathrm{T}_{\mathrm{inl}}-$ is the error in calculation of inlet temperature in FA, which makes at most $3.5 \% ; \Delta \mathrm{A}-$ is the error in maximum linear power $(4.2 \%) ; \Delta_{\mathrm{pr}}-$ is the error caused by inaccuracies of calculating the thermal physical properties of water, which makes at most $2 \%$.

All original inaccuracies are obtained from operation experience, taken as hardware performance data or from calculation evaluations, etc.

\section{RELIABILITY PARAMETERS FOR SIGNAL GENERATING FUNCTION OF PROTECTION SYSTEM USING LOCAL PARAMETERS}

In calculation of reliability parameters, we assumed an exponential law for distribution of failure-free operation period and for recovery period, which have parameters $\lambda$ and $\mu$, respectively [5].

Reliability calculations were performed by way of summarising failure intensivity ( $\lambda$ method).

For this purpose, $\lambda$ characteristics of equipment elements were selected with allowance for load factors.

Where foreign-made equipment components were used, we used the reliability data from the catalogues issued by the companies that produce these components. If the required data were unavailable (this is mainly related to microcircuits), we accepted the reliability data of the Russian-made analogues (conservative assessment).

A failure of signal generating function using local parameters is considered to be the failure to give a command, even if a requirement of this command exists (rejection of requirement); or unreasonable command (spurious command).

The reliability calculation of the signals is performed proceeding from the fact that the ICIS structure is capable to provide power density monitoring in every FA section using SPND signals coming from six various ICIDs (that surround a FA), each of which has a connection to independent PTK-Z channel.

\section{Reliability indicators of departure from nucleate} boiling ratio

Failure intensity: $2.46 \cdot 10^{-9} 1 / \mathrm{h}$.

Failure run: $4.1 \cdot 10^{8} \mathrm{~h}$.

Frequency of spurious actuation per year: $3.3 \cdot 10^{-4} 1 /$ year. Probability of requirement rejection: $7.3 \cdot 10^{-8}$.

\section{Reliability indicators of fuel rod local power}

Failure intensity: $0.28 \cdot 10^{-9} 1 / \mathrm{h}$

Failure run: $3.6 \cdot 10^{9} \mathrm{~h}$.

Frequency of spurious actuation per year: $2.9 \cdot 10^{-5}$ 1/year. Probability of requirement rejection: $6.2 \cdot 10^{-8}$.

\section{CONCLUSIONS}

This investigation findings prove the possibility to integrate in ICIS (PTK-Z) the function of automatic protection of $\mathrm{V}-412$ core on the basis of local parameters.

The article presents the following PTK-Z block structure with indicated data links and safety categories; 
algorithms for processing SPND signals important for determination of local parameters in each part of the core in both normal and abnormal operation conditions; inaccuracies of maximum linear power with various positions of CPS CR (i.e the entire bank is submerged, and one CR is stuck) at the beginning or end of the cycle.

Thus, the calculated investigation proved that the engineering solution (conception, selected composition, structure, calculation algorithms, detector arrangement in the core or safety channels, statistical weight and organisation of recalibration process) of protection system using local parameters ensures generating scram signals, when the local parameters reach design limitations with additional methodological inaccuracy that makes $\pm 2 \%$ at most, including a single failure, and satisfies the requirements of TA for MCDS of V-412 reactor unit.

\section{REFERENCES}

1. General Provisions for Nuclear Plant Safety Assurance OPB-88/97. NP-001-97 (PNAE G-01-01197).

2. Kudankulam NPP. Unit 1. Quality Categories for APCS. Classification and Application. R01.KK.0.0.AP.KL.WD001. 2005.

3. Kudankulam NPP. Units 1, 2. Design project. Monitoring, Control and Diagnostic System. Description of Automatic Functions. KK.UJA.JD.AP.PZ.PR141 412.17 D9.

4. Kudankulam NPP. Unit 1, 2. Design project. Monitoring, Control and Diagnostic System. Technical Requirements for Monitoring. Control and Diagnostic System. KK.UJA.JD.AP.TT.PR086 412.17 D1.

5. Kudankulam NPP. Unit 1, 2. Final safety analysis report. Topic report. Protection function reliability survey and analysis based on local parameters. R21.KK.0.0.OO.FSAR.WD0P0. 2006.

6. S.A. Yeremeyev, V.M. Vasin, M.A. Podshibyakin. Sovershenstvovaniye kontrolya minimal'nogo zapasa do krizisa teplootdachi kak kharakteristiki teplotekhnicheskoy nadezhnosti aktivnoy zony WWER: Sbornik trudov 11-y Mezhdunarodnoy nauchnotekhnicheskoy konferentsii "Obespecheniye bezopasnosti AES s WWER" 21-24 maya 2019 g., Podol'sk, AO OKB "GIDROPRESS", 2019 (in Russian).

7. A.A. Gagarinskiy, A.V. Markov. Kaskad Code Package. Code BIPR-7A. Description of Algorithm. Operation Instruction. Inv. No.32/1-52-402. M., 2002.

8. S.S. Aleshin, S.N. Bolshagin, M.Y. Tomilov. Code PERMAK-A. (Versions 1, 3) Operation Instruction. Inv. No.32/1-175-401. M., 2001.

9. A.P. Lazarenko, S.S. Aleshin, M.Ju. Tomilov, A.S. Bikeev, D.A. Shkarovsky. Software Package KASKAD for Neutronic Calculation of WWER Cores. Status and Features // 12 International conference on WWER fuel performance, modelling and experimental support, Nesebar (Bulgaria), 16-23 Sep. 2017, 8 p.

\section{ACRONIMS}

APCS - automatic process control system;

$\mathrm{CA}$ - commissioning activities;

CPS CR - control and protection system control rods;

FA - fuel assembly;

ICID - in-core instrumentation detectors;

ICIS - in-core instrumentation system;

MCDS - monitoring, control and diagnostic system;

MSD - mean square deviation;

NPP - nuclear power plant;

$\mathrm{PP}$ - preventive protection;

PPO - application software;

PTK-Z - safety system software-hardware;

RCPS - reactor coolant pump set;

SPND - self-powered neutron detector;

RCU - rapid core unloading;

TA - technical assignment;

VK ICIS - computer complex of in-core instrumentation system.

\title{
АНАЛИЗ НАДЕЖНОСТИ ФУНКЦИЙ ЗАЩИТЫ АКТИВНОЙ ЗОНЫ РЕАКТОРА В-412 ПО ЛОКАЛЬНЫМ ПАРАМЕТРАМ: МАКСИМАЛЬНАЯ ЛИНЕЙНАЯ МОЩНОСТЬ, ЗАПАС КРИЗИСА ТЕПЛООТДАЧИ
}

\author{
С.С. Лис, М.М. Семерак, А.И. Канюка
}

Объектом исследования является техническое решение задачи обеспечения автоматической защиты активной зоны реактора В-412 по локальным параметрам (максимальная линейная мощность, запас до кризиса теплоотдачи) в процессе эксплуатации в базовом и переходном режимах в рамках системы внутриреакторного контроля (СВРК), реализуемой программно-техническим комплексом защиты (ПТК-3) с использованием сигналов внутриреакторных датчиков нейтронного потока, температуры, расхода и давления теплоносителя первого контура. В процессе работы проводилось расчетное обоснование применения фильтров Калмана и корректирующего фильтра для устранения запаздывания датчика прямой зарядки (ДПЗ), определения методической погрешности контроля максимальной линейной мощности в активной зоне. Показано, что решение задачи обеспечения автоматической защиты активной зоны реактора B-412 по локальным параметрам было найдено с учетом накопленного опыта внутриреакторных измерений, а также проектирования и эксплуатации СВРК на базе повышения метрологических, надежностных и временных характеристик с использованием возможностей современных информационных технологий для ответственных применений и с учетом требований нормативных документов. 


\title{
АНАЛІЗ НАДІЙНОСТІ ФУНКЦІЙ ЗАХИСТУ АКТИВНОЇ ЗОНИ РЕАКТОРА В-412 ЗА ЛОКАЛЬНИМИ ПАРАМЕТРАМИ: МАКСИМАЛЬНА ЛІНІЙНА ПОТУЖНІСТЬ, ЗАПАС ДО КРИЗИ ТЕПЛОВІДДАЧІ
}

\author{
С.С. Лис, М.М. Семерак, О.І. Канюка
}

Об'єктом дослідження є технічне вирішення задачі забезпечення автоматичного захисту активної зони реактора В-412 по локальних параметрах (максимальна лінійна потужність, запас до кризи тепловіддачі) в процесі експлуатації в базовому і перехідному режимах у рамках системи внутрішньореакторного контролю (СВРК), що реалізовується програмно-технічним комплексом захисту (ПТК-3) з використанням сигналів внутрішньореакторних датчиків нейтронного потоку, температури, витрати і тиску теплоносія першого контуру. В процесі роботи проводилося розрахункове обгрунтування застосування фільтрів Калмана $\mathrm{i}$ коригуючого фільтра для усунення запізнювання датчика прямої зарядки (ДПз), визначення методичної похибки контролю максимальної лінійної потужності в активній зоні. Показано, що рішення задачі забезпечення автоматичного захисту активної зони реактора В-412 по локальних параметрах було знайдено 3 урахуванням накопиченого досвіду внутрішньореакторних вимірювань, а також проектування $\mathrm{i}$ експлуатації СВРК на базі підвищення метрологічних, надійнісних i тимчасових характеристик 3 використанням можливостей сучасних інформаційних технологій для відповідальних застосувань і 3 урахуванням вимог нормативних документів. 